九州大学学術情報リポジトリ

Kyushu University Institutional Repository

Biomass Production and Synthes is of Biodiesel from Microalgae Synechococcus HS-9 (Cyanobacteria) Cultivated Using Bubble Column Photobioreactors

Rahman, Arif

Department of Mechanical Engineering, Faculty of Engineering, Universitas Indonesia

Nining Betawati Prihantini

Department of Biology, Faculty of Mathematics and Natural Sciences, Universitas Indonesia

Nasrudd in

Department of Mechanical Engineering, Faculty of Engineering, Universitas Indonesia

https://doi.org/10.5109/4150507

出版情報 : Evergreen. 7 (4)，pp.564-570，2020-12. 九州大学グリーンテクノロジー研究教育センター バージョン：

権利関係 : 


\title{
Biomass Production and Synthesis of Biodiesel from Microalgae Synechococcus HS-9 (Cyanobacteria) Cultivated Using Bubble Column Photobioreactors
}

\author{
Arif Rahman ${ }^{1}$, Nining Betawati Prihantini ${ }^{2}$, Nasruddin ${ }^{1, *}$ \\ ${ }^{1}$ Department of Mechanical Engineering, Faculty of Engineering, Universitas Indonesia, Kampus UI Depok, \\ Depok 16424, West Java, Indonesia \\ ${ }^{2}$ Department of Biology, Faculty of Mathematics and Natural Sciences, Universitas Indonesia, Kampus UI
} Depok, Depok 16424, West Java, Indonesia

*Author to whom correspondence should be addressed: E-mail:."nasruddin@eng.ui.ac.id

(Received November 4, 2020; Revised December 9, 2020; accepted December 16, 2020).

\begin{abstract}
The increasing demand for energy has resulted in the current worldwide energy crisis. The uncontrolled use of fossil fuels has resulted in severe negative impacts on human health and the environment. Therefore, an alternative, renewable natural resource is required to fulfill the world's energy needs. Indonesia has a potential alternative energy source: microalgae-based biofuel is renewable and can be further developed. The aim of this study was to determine the productivity of microalgae biomass, the effect of temperature and time on the transesterification reaction, content and composition of biodiesel (FAME). The general processes were cultivation using bubble column photobioreactors, harvesting, lipid extraction from the biomass, and biodiesel synthesis using transesterification. The cultivation of 7.5 L Synechococcus HS-9 resulted in $5.3 \mathrm{~g}$ of microalgae wet biomass and $3.32 \mathrm{~g} / \mathrm{L}$ of dry biomass. The synthesis of biodiesel using transesterification was influenced by both temperature and reaction time. Here, a $5.5 \%$ biodiesel yield was obtained at $55^{\circ} \mathrm{C}$ in 60 min. The highest biodiesel yield was $4.25 \%$ in 30 min at $65{ }^{\circ} \mathrm{C}$. The FAME contents of Synechococcus HS-9 microalgae biodiesel were 3.16\%, $18.96 \%$, and $77.87 \%$ monounsaturated fatty acids, polyunsaturated fatty acids, and saturated fatty acids, respectively.
\end{abstract}

Keywords: biodiesel; FAME; microalgae; photobioreactor; Synechococcus

\section{Introduction}

Indonesia has relatively large energy resources from fossil fuels; however, at some point, a crisis will occur when the resources are inevitably depleted by the increasing energy consumption. Between 2007 and 2017, energy consumption in Indonesia increased by almost $38 \%$ and predicted to continue to rise in the future ${ }^{1,2)}$. In addition, the negative impact of fuel consumption is very worrying, to the extent that renewable natural resources are needed as alternatives to meet the country's energy needs. According to available data on renewable energy and fossil energy reserves in the world, Indonesia has the potential to develop new renewable energy in fields such as hydroelectric power plants, solar power electric generators, geothermal power plants, marine energy, bioenergy, bio-oil, biofuel (biodiesel and bioethanol) and pure plant oil ${ }^{3,4,5,6)}$.
As a country with rich natural resources, Indonesia could develop biofuel and produce approximately 200 barrels per day (bpd) from the first and second generation of biofuel 4). The largest production of biofuel in Indonesia from palm oil (first generation of biofuels). A potential environmentally friendly biofuel is biodiesel derived from microalgae (the third generation). It is primarily a sustainable, clean fuel that is environmentally friendly, non-toxic and free of harmful sulfur ${ }^{7,8}$. Biodiesel, also known as the fatty acid methyl ester (FAME), is a renewable fuel which is considered an attractive replacement for conventional diesel fuels ${ }^{9)}$.

Microalgae are a group of photosynthetic microorganisms, so named for their ability to harness the energy of sunlight and absorb carbon dioxide $\left(\mathrm{CO}_{2}\right)$ from the environment for photosynthesis. Microalgae biomass contains lipids that can be used as raw material for biodiesel and glycerin ${ }^{10,11)}$. The research and development of biofuels such as biodiesel have been conducted for a 
long time, having gone through three development periods. As a source of third-generation biofuel, microalgae yield a higher percentage of biodiesel than first- and secondgeneration biofuels derived from food and non-food crops such as palm, palm oil, rapeseed, soybean, castor, and gasification $^{12,13)}$. On the basis of research carried out by Rajvashi et al. in 2012, microalgae have a biodiesel percentage of $70 \%$, which is higher than that of corn (44\%), soybean ( $28 \%)$, castor $(28 \%)$, sunflower $(40 \%)$, and palm oil $(36 \%)^{14)}$. Microalgae contain different percentages of biodiesel. Chlorella emorsoni has 39.7\% biodiesel, Botryococcus braumii has $50.7 \%{ }^{15)}$, Spirulina maxima has $86.1 \%{ }^{16)}$, Synechococcus has $37 \%{ }^{17)}$, Synechococcus elongates has $38.8 \%^{18)}$, Nannochloropsis has $46 \%{ }^{19)}$, Nitzschia sp. has $46 \%{ }^{20)}$ and Synechococcus sp. PCC7942 has $55.6 \%{ }^{21)}$.

Microalgae require a lengthy process to produce biodiesel. Generally, the processes are cultivation, harvesting, extraction of lipids from the biomass, and biodiesel synthesis. Several studies have been conducted, including that conducted by Amit Kumar Sharma et al., In 2016 which examined Chlorella vulgaris. This study used the raceway pond cultivation method and the harvesting method used the flocculation and filtration processes. Lipid extraction used the soxhlet method and biodiesel synthesis using the transesterification method ${ }^{22)}$. Another study conducted by Suzana Wahidin et al., 2016 which carried out the cultivation of Nannochloropsis sp. using a photobioreactor. Biodiesel synthesis uses the transesterification method with the help of simultaneous reactions in microwave irradiation ${ }^{23}$. In 2017, a study conducted by M. Mashayekhi et al., Who used the Synechococcus elongatus. The microalgae were grown in a $500 \mathrm{~mL}$ erlenmeyer using BG-11 medium. Lipid extraction used the modified Bligh-Dyer method and the biodiesel synthesis process used the transesterification method $^{24)}$.

In this study, bubble column photobioreactors (BCP) were used for the cultivation of Synechococcus HS-9. BCP is used more commonly than other photobioreactors. Mixing and mass transfer were conducted by spargers with external light supply. Photosynthetic effiency depends on gas flow rate, which also relies on gas on the light and dark cycle, the liquid is circulated periodically at a higher gas flow rate from the dark central zone to the external photic field. Photosynthetic efficiency can be increased by increasing the gas flow rate ${ }^{25)}$ BCP is a simple conceptual design and the most economical design to construct ${ }^{26)}$. BCP use rising gas bubble to facilitate gas exchange and mix the reactor. This approach controls light and temperature to a certain extent but it a way that is cost effective $^{27)}$. The biomass obtained from cultivation was used for lipid extraction via the Bligh-Dyer method. The lipids were then utilized for biodiesel synthesis by transesterification. The effect of variations in reaction temperature and reaction time on the produced biodiesel was also investigated. Overall, this research is new: specifically, the use of microalgae Synechococcus HS-9 from hot spring area in Banten-Indonesia.

\section{Methods}

\subsection{Cultivation of microalgae Synechococcus HS-9}

Microalgae cultivation was carried out using BCPs, and the inoculation process was conducted by adding microalgae inoculums and NPK medium into a $7 \mathrm{~L}$ photobioreactor at a ratio of 1:35 v/v. The flow rate was 4 liter per minute (LPM) and measured using rotameter. The light intensity was 1000 lux and measured using a Lux Meter LX-1128SD. Cultivation was carried out until the growth of the microalgae reached a stationary phase, and then the optical density was periodically measured using an ultraviolet-visual light (UV-VIS) spectrophotometer.

\subsection{Net energy ratio analysis}

The net energy ratio (NER) is an energy system evaluation technique that is calculated by comparing the total produced energy and the energy needed in a production process ${ }^{28}$. Here the NER value was analyzed during the Synechococcus HS-9 microalgae cultivation for 60 days. The NER value indicates the energy economic status of the production process, that is, the higher the NER value, the more efficient the production process in terms of using energy. The NER value of each superficial gas velocity $\left(\mathrm{U}_{G}\right)$ be calculated based on Equations (1)$(4)^{29)}$ :

$$
\mathrm{NER}=\frac{\mathrm{E}_{\mathrm{OUT}}}{\mathrm{E}_{\mathrm{IN}}}
$$

$E_{\text {OUT }}$ is energy that can be obtained from the biomass or lipids produced $(\mathrm{kJ})$ and $\mathrm{E}_{\mathrm{IN}}$ is the energy needed for the aeration process in BCP $(\mathrm{kJ})$. Eout value can be calculated based on the calorific values of biomass or lipid generated.

$$
\mathrm{E}_{\mathrm{OUT}}=\mathrm{C}_{\mathrm{X}} * \mathrm{~V}_{\mathrm{P}} * \text { Cal }
$$

$\mathrm{C}_{\mathrm{X}}$ is the concentration of biomass or lipid $(\mathrm{g} / \mathrm{L}), \mathrm{V}_{\mathrm{P}}$ is the volume of the photobioreactor $(\mathrm{L})$ and $\mathrm{Cal}$ is the caloric value of the biomassa or lipid $(\mathrm{kJ} / \mathrm{g})$. Based on in a study by Lardon L., the caloric value of a lipid $\left(\mathrm{C}_{40} \mathrm{H}_{74} \mathrm{O}_{5}\right)$ was $38.3 \mathrm{MJ} / \mathrm{kg}^{30}$. E E value canbe calculated based on the power used and cultivation time.

$$
\begin{aligned}
& \mathrm{E}_{\mathrm{IN}}=\mathrm{P}_{\mathrm{G}} * \mathrm{t} \\
& \frac{P_{G}}{V_{L}}=\frac{\rho_{L} * g * U_{G}}{1+\frac{A_{d}}{A_{r}}}
\end{aligned}
$$

$\mathrm{P}_{\mathrm{G}}$ is the power used during the aeration process $(\mathrm{W}), \mathrm{t}$ is the cultivation time $(\mathrm{s}), \mathrm{V}_{\mathrm{L}}$ is the volume of culture $\left(\mathrm{m}^{3}\right)$, $\mathrm{g}$ is the gravity $\left(\mathrm{m} / \mathrm{s}^{2}\right)$. $U_{G}$ is the superficial gas velocity $(\mathrm{m} / \mathrm{s}), A_{d}$ is the area of the downcomer $\left(\mathrm{m}^{2}\right)$, and $A_{r}$ is the area of the riser $\left(\mathrm{m}^{2}\right)$. $\mathrm{U}_{\mathrm{G}}$ values in the riser area can be calculated between airflow velocity (Q) with the riser area. 


\subsection{Lipid extraction}

Lipid extraction was carried out via the modified Bligh-Dyer method by adding methanol and chloroform $(2: 1 \mathrm{v} / \mathrm{v})$. Then, lipid was ultrasonication at a frequency of $34 \mathrm{kHz}$ for $30 \mathrm{~min}$, followed by adding chloroform and distilled water $(1: 1 \mathrm{v} / \mathrm{v})$ and subsequent cultivation, again for $30 \mathrm{~min}$. The product was separated using a centrifuge at a speed of $6000 \mathrm{rpm}$ for $15 \mathrm{~min}$.

\subsection{Biodiesel synthesis}

Transesterification was used to synthesize microalgae biodiesel with the aid of $\mathrm{KOH}$ as a catalyst. Biodiesel synthesis included the addition of the lipid of Synechococcus HS-9 and methanol at a molar ratio of 1:10 and a $\mathrm{KOH}$ catalyst of mass $5 \% \mathrm{w} / \mathrm{w}$ with respect to that of the lipid. Then, they were heated at $60{ }^{\circ} \mathrm{C}$ using a hotplate stirrer. After reaching $60{ }^{\circ} \mathrm{C}$, the mixture was reacted at a stirring speed of $250 \mathrm{rpm}$, and its temperature was maintained for $60 \mathrm{~min}$. After the reaction was complete, the product was separated from the catalyst by a centrifuge at $8500 \mathrm{rpm}$. The product was then separated from the solvent by evaporation on a hotplate at $60^{\circ} \mathrm{C}$. The experiment was repeated with variations in the reaction time (30 and $90 \mathrm{~min}$ ) and temperature (55 and $\left.65^{\circ} \mathrm{C}\right)$.

\subsection{Biodiesel characterization}

Biodiesel characterization was performed by calculating the amount of biodiesel yield, composition, and fatty acid methyl ester (FAME) content. The biodiesel yield produced was calculated using Equation (5):

$$
\mathrm{Y}_{\overline{\mathrm{B}}}(\%)=\frac{\mathrm{m}_{\mathrm{B}}}{\mathrm{m}_{\mathrm{L}}} \times 100 \%
$$

Experimental set up and flow chart of the process biodiesel synthesis as shown in Figure 1 and 2.



Fig 1. Experimental set up



Fig 2. Flow chart of research on biodiesel synthesis from Synechococcus HS-9

\section{Experimental results}

\subsection{Cultivation of Synechococcus HS-9}

The cultivation process was carried out for 60 days using NPK medium at $80 \mathrm{ppm}^{31)}$, an aeration rate of 4 LPM, a light intensity value of $1000 \mathrm{Lux}$, a culture $\mathrm{pH}$ of 8-6, and a temperature of $36-39^{\circ} \mathrm{C}$. The Synechococcus HS-9 growth curves show biomass dry weight $(\mathrm{X})$ and biomass productivity (BP) over time (t) in Figure 3. 


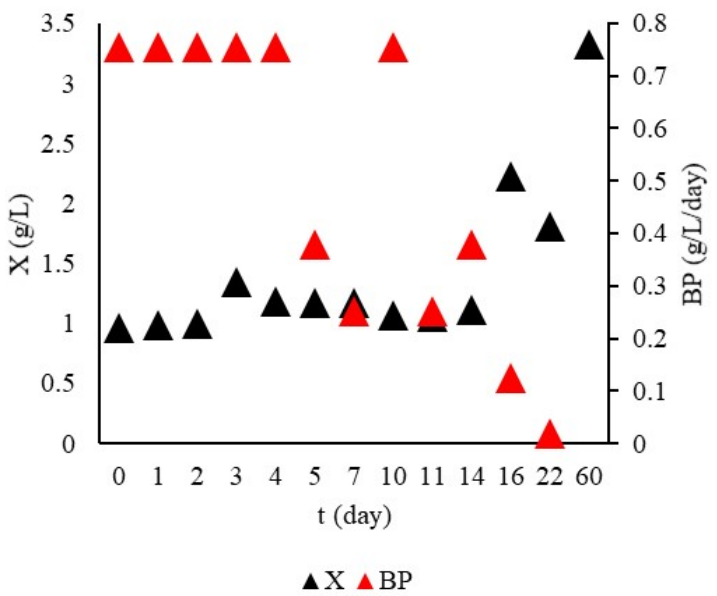

Fig. 3: Relationship of biomass dry weight and biomass productivity.

The dry biomass weight curve was obtained from the linear relationship between biomass dry weight and $\mathrm{OD}_{649}$ in the form of an $\mathrm{OD}_{649}$ calibration curve, whereas BP was obtained from the relationship between biomass concentration and cultivation time. In Figure 3, the weight of dry biomass is proportional to the OD value measured during the cultivation process. The dry biomass of Synechococcus HS-9 obtained on the third day was 1.34 $\mathrm{g} / \mathrm{L}$, on the $16^{\text {th }}$ day it was $2.23 \mathrm{~g} / \mathrm{L}$, and on the 60 th day it was $3.32 \mathrm{~g} / \mathrm{L}$. The optimum BP was $0.76 \mathrm{~g} / \mathrm{L} /$ day.

\subsection{Net energy ratio during cultivation}

The total energy needed during aeration $\left(\mathrm{E}_{\mathrm{IN}}\right)$ in the BCP was $582 \times 10^{7} \mathrm{~kJ}$, and the total energy that could be obtained from the biomass or lipids produced ( $E_{\text {OUT }}$ ) was $1145.43 \mathrm{~kJ}$. On the basis of these results, the NER value in the aeration process during the cultivation of Synechococcus HS-9 for 60 days using the BCP was $2 \times$ $10^{-5}$, whereas the average NER value per day was $3.3 \times$ $10^{-7}$. The aeration process during cultivation was inefficient (3.2 $\times 10^{-1}$ with 6 -day cultivation) compared with that found in previous studies using BCPs. Thus, the average daily NER value generated was $5.3 \times 10^{-2} 32$ )

\subsection{Lipid extraction}

The amount of lipids that could be extracted was influenced by microalgae biomass condition, type of solvent, and extraction method. In this research, the extraction of Synechococcus HS-9 as a biodiesel synthesis material was carried out by the Bligh-Dyer method using wet-based biomass. Here, lipid extraction results in a 35.90 g total wet lipid still mixed with chloroform.

\subsection{Biodiesel synthesis}

The synthesis of microalgae biodiesel was carried out using transesterification. Transesterification was performed by varying the reaction time and temperature, as these are parameters that affect the transesterification reaction and biodiesel yield.

\subsubsection{Effect of reaction temperature on biodiesel yield}

The reaction temperature was varied (55, 60 and $65{ }^{\circ} \mathrm{C}$ ) and the reaction time was maintained for 60 minutes. On the basis of Figure 4, the yield of biodiesel was $5.5 \% \mathrm{w} / \mathrm{w}$ at $55^{\circ} \mathrm{C}, 5.3 \% \mathrm{w} / \mathrm{w}$ at $60^{\circ} \mathrm{C}$, and $3.6 \% \mathrm{w} / \mathrm{w}$ at $65^{\circ} \mathrm{C}$. The highest yield of biodiesel was produced at $55^{\circ} \mathrm{C}$ and did not significantly differ from that obtained at $60{ }^{\circ} \mathrm{C}$. This can be explained as follows. An increase in temperature is followed by an increase in the reaction speed (biodiesel formation). The higher the temperature, the greater the resulting conversion. When the reaction speed increases, the required reaction time reduces. This is inversely proportional to the relatively long reaction time, such that the number of triglycerides that function as reactants is insufficient for longer reaction periods.

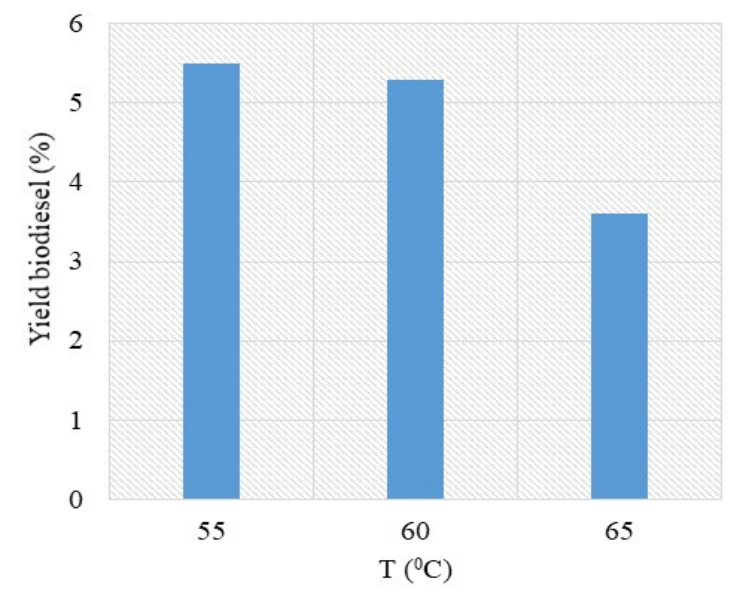

Fig. 4: Effect of reaction temperature on biodiesel yield.

\subsubsection{Effect of reaction time on biodiesel yield}

The reaction time was varied (30, 60 and 90 minutes) and the reaction temperature was kept constant at $65^{\circ} \mathrm{C}$. The choice of temperature, $65{ }^{\circ} \mathrm{C}$, was kept constant because at that temperature methanol approaches its boiling point. Figure 5 shows that the reaction time is very influential on the produced biodiesel yield. In the 30-min synthesis, the biodiesel yield was $4.2 \% \mathrm{w} / \mathrm{w}$; for the 60 min and 90-min reactions, the yields were $3.6 \%$ and $3.55 \% \mathrm{w} / \mathrm{w}$, respectively.

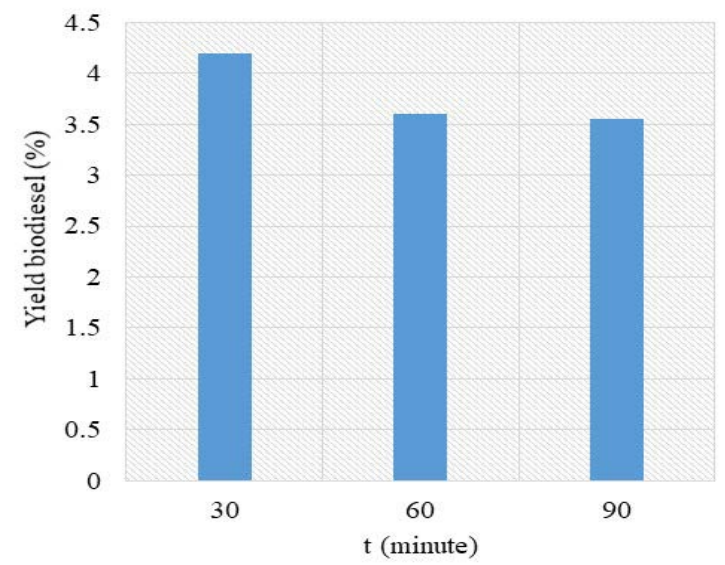

Fig. 5: Effect of reaction time on biodiesel yield. 


\subsubsection{Content and composition of biodiesel}

As shown in Table 1, the composition of fatty acids formed from Synechococcus HS-9 microalgae biodiesel was dominated by saturated fatty acids $(39.7 \% n$ hexadecanoic, $14.88 \%$ tetradecanoic, and $11.12 \%$ hexadecanoic acids, 15-methyl-, and methyl esters). The second composition of fatty acids, namely polyunsaturated fatty acids such as octadecanoic acid, was $15.63 \%$. There was also a small percentage of monounsaturated fatty acids, specifically $2.47 \%$ of oleic acid.

Table 1. Composition of fatty acid methyl ester (FAME) in Synechococcus HS-9 microalgae biodiesel

\begin{tabular}{|c|c|c|c|c|}
\hline No. & FAME & $\begin{array}{l}\text { Molecular } \\
\text { Formula }\end{array}$ & $\begin{array}{l}(\% \\
\mathrm{w} / \mathrm{w})\end{array}$ & $\begin{array}{l}\text { Fatty } \\
\text { acid }\end{array}$ \\
\hline 1 & $\begin{array}{l}\text { 9-Hexadecanoic } \\
\text { acid, methyl } \\
\text { ester, }(Z) \text { - }\end{array}$ & $\mathrm{C}_{17} \mathrm{H}_{32}$ & 0,35 & \multirow{3}{*}{$\begin{array}{l}\text { Mono } \\
\text { unsatu } \\
\text { rated }\end{array}$} \\
\hline 2 & $\begin{array}{l}\text { 9-Octadecanoic } \\
\text { acid (Z)-, methyl } \\
\text { ester }\end{array}$ & $\mathrm{C}_{19} \mathrm{H}_{36}$ & 0,35 & \\
\hline 3 & Oleic acid & $\mathrm{C}_{18} \mathrm{H}_{34}$ & 2,47 & \\
\hline 4 & Eicosanoic acid & $\mathrm{C}_{20} \mathrm{H}_{40}$ & 0,29 & \multirow{4}{*}{$\begin{array}{l}\text { Polyu } \\
\text { nsatur } \\
\text { ated }\end{array}$} \\
\hline 5 & $\begin{array}{l}\text { Eicosanoic acid, } \\
\text { methyl ester }\end{array}$ & $\mathrm{C}_{21} \mathrm{H}_{42}$ & 0,65 & \\
\hline 6 & $\begin{array}{l}\text { Heptadecanoic } \\
\text { acid, methyl } \\
\text { ester }\end{array}$ & $\mathrm{C}_{18} \mathrm{H}_{36}$ & 2,40 & \\
\hline 7 & $\begin{array}{l}\text { Octadecanoic } \\
\text { acid }\end{array}$ & $\mathrm{C}_{18} \mathrm{H}_{36}$ & 15,63 & \\
\hline 8 & $\begin{array}{l}\text { Hexadecanoic } \\
\text { acid, 15- } \\
\text { methyl-, methyl } \\
\text { ester }\end{array}$ & $\mathrm{C}_{18} \mathrm{H}_{36}$ & 6,98 & \multirow{5}{*}{$\begin{array}{l}\text { Satura } \\
\text { ted }\end{array}$} \\
\hline 9 & $\begin{array}{l}\text { Hexadecanoic } \\
\text { acid, methyl } \\
\text { ester }\end{array}$ & $\mathrm{C}_{17} \mathrm{H}_{34}$ & 11,12 & \\
\hline 10 & $\begin{array}{l}\text { Methyl } \\
\text { tetradecanoate }\end{array}$ & $\mathrm{C}_{15} \mathrm{H}_{30}$ & 5,14 & \\
\hline 11 & $\begin{array}{l}n \text {-Hexadecanoic } \\
\text { acid }\end{array}$ & $\mathrm{C}_{16} \mathrm{H}_{32}$ & 39,75 & \\
\hline 12 & $\begin{array}{l}\text { Tetradecanoic } \\
\text { acid }\end{array}$ & $\mathrm{C}_{14} \mathrm{H}_{28}$ & 14,88 & \\
\hline
\end{tabular}

According to Table 1 , the content of fatty acids found in Synechococcus HS-9 was dominated by hexadecanoic acid. These results are almost the same as those of a previous study conducted by Prihnatini in 2018, where fatty acids in the form of saturated fatty acids 16:0 [hexadecanoic acid/palmitic acid/ $\mathrm{CH}_{3}\left(\mathrm{CH}_{2}\right)_{14} \mathrm{COOH}$ ] made up about 23.23 to $42.64 \%$. This is because the fatty acids contained in cyanobacteria cells are a phenotypic group that can be used to determine the taxonomic position, including for the genus Synechococcus HS-9 ${ }^{33}$.

On the basis of Figure 6, the values of monounsaturated fatty acid, polyunsaturated fatty acid, and saturated fatty acid were $3.16 \%, 18.96 \%$, and $77.87 \%$, respectively. These results indicate that the FAME composition of Synechococcus HS-9 allows it to be a promising raw material for producing biodiesel because the amount and ratio of fatty acids (saturated and unsaturated) are key in determining the suitability of microalgae as a raw material for biodiesel.

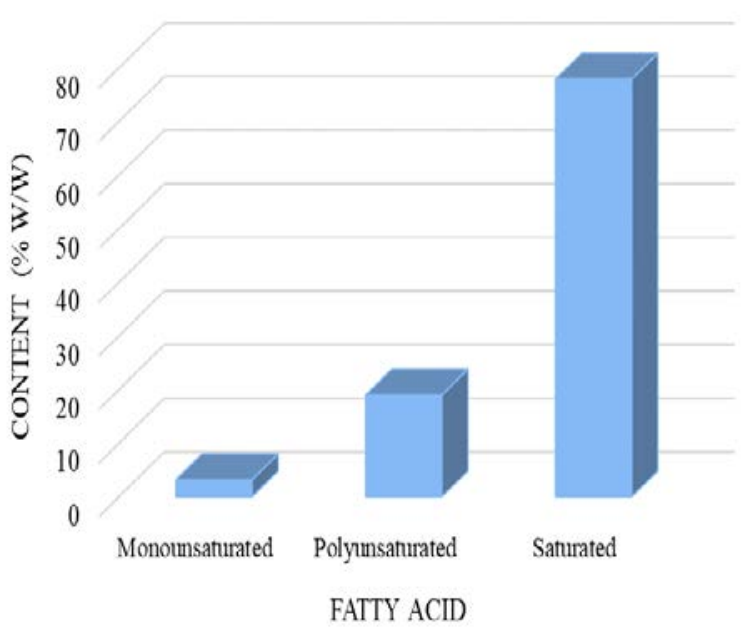

Fig. 6: Percentage of fatty acid methyl esters.

\section{Conclusion}

According to our analysis, the cultivation of Synechococcus HS-9 resulted in $5.52 \mathrm{~g}$ of wet microalgae biomass and $3.323 \mathrm{~g} / \mathrm{L}$ of dry biomass. Biodiesel synthesis based on transesterification is affected by both temperature and reaction time. In this study, a biodiesel yield of $5.5 \%$ was obtained at $55^{\circ} \mathrm{C}$ for $60 \mathrm{~min}$, and the highest biodiesel yield of $4.25 \%$ was obtained at $65^{\circ} \mathrm{C}$ for $30 \mathrm{~min}$. The FAME content of Synechococcus HS-9 biodiesel cultivated using NPK 80 ppm medium in BCPs was $18.96 \%$ for polyunsaturated fatty acids, $3.16 \%$ for monounsaturated fatty acids, and $77.87 \%$ for saturated fatty acids.

\section{Acknowledgments}

The author thanks The Ministry of Research and Technology / National Research and Innovation Agency of Republik Indonesia (KEMENRISTEK/BRIN RI) for funding this research on the Master program toward a Doctorate for Superior Bachelor (PMDSU) 2020 with contract number NKB-445/UN2.RST/HKP.05.00/2020.

\section{Nomenclature}

$Y_{B} \quad$ yield of biodiesel (\%)

$m_{B} \quad$ mass of biodiesel (gr)

$m_{L} \quad$ mass of wet lipid (gr)

EOUT energy produced (kJ) 
$E_{I N} \quad$ energy during aeration $(\mathrm{kJ})$

$C_{X} \quad$ concentration of biomass/lipid (g/L)

$V_{P} \quad$ volume of photobioreactor (L)

Cal calory of biomass/lipid $(\mathrm{kJ} / \mathrm{g})$

$P_{G} \quad$ power $(\mathrm{W})$

$t \quad$ time of cultivation (s)

$V_{L} \quad$ volume of water $\left(\mathrm{m}^{3}\right)$

$\rho_{L} \quad$ water density $\left(\mathrm{kg} / \mathrm{m}^{3}\right)$

$G \quad$ gravity $\left(\mathrm{m} / \mathrm{s}^{2}\right)$

$U_{G} \quad$ superficial gas velocity $(\mathrm{m} / \mathrm{s})$

$A_{d} \quad$ downcomer area $\left(\mathrm{m}^{2}\right)$

$A_{r} \quad$ riser area $\left(\mathrm{m}^{2}\right)$

\section{References}

1) ESDM, K., Handbook of Energy \& Statistics of Indonesia. 2018, Kementerian Energi dan Sumber Daya Mineral: Jakarta.

2) Kuncoro, A. and W. Purwanto, Analysis of EnergyWater Nexus Palm Oil Biodiesel Production in Riau Using Life Cycle Assessment and Water Footprint Methods. Evergreen, 2020. 7(1): p. 104-110.

3) A. Webb, and D.J.C.T.S. Coates, Biofuels and Biodiversity., 6569 (2012).

4) ESDM, K., Energi Baru Dan Terbarukan, D.J.E.B.T.D.K. Energi, Editor. 2017, Kementrian Energi Dan Sumber Daya Mineral: Jakarta.

5) Paryanto, I., et al., The effect of outdoor temperature conditions and monoglyceride content on the precipitate formation of biodiesel-petrodiesel blended fuel (Bxx). Evergreen, 2019. 6(1): p. 59-64.

6) Kusrini, E., et al., Effect of Polypropylene Plastic Waste as Co-feeding for Production of Pyrolysis Oil from Palm Empty Fruit Bunches. Evergreen, 2019. 6(1): p. 92-97.

7) Hidayat, A., et al., Biodiesel production from rice bran oil over modified natural zeolite catalyst. International Journal of Technology, 2018. 9(2): p. 400-411.

8) Rizaldi, M.I., A. Rahman, and N.B. Prihantini, Generation of microbubbles through single loop and double loop fluid oscillator for photobioreactor aeration. International Journal of Technology, 2019. 10(7): p. 1446-1452.

9) Nabilla, S., et al., Fatty Acid Methyl Ester Synthesis in the Cold Plasma Reactor using CO_2 and Steam Mixture. Evergreen, 2020. 7(2): p. 275-279.

10) U. Enwereuzoh, and G.J.A.J.E.R. Onyeagoro, A Novel Aeration Method For The Preparation Of Algae (Dunaliella Salina) Biomass For Biofuel Production., 3 (9) 209-214 (2014).

11) A. Rahman, N.B. Prihantini, and Nasruddin. Fatty Acid Of Microalgae As A Potential Feedstock For Biodiesel Production In Indonesia. In AIP Conference Proceedings. 2019. AIP Publishing.

12) A. Amy, and S.J.J.T.S.S.D.D. Agus, Perancangan Produk Reaktor Mikroalga Penghasil Biofuel Untuk Kawasan Pesisir. 2012(1).
13) M. Mofijur, et al., Recent Development in the Production of Third Generation Biodiesel from Microalgae., 156 53-58 (2019).

14) Rajvanshi, S. And M.P.J.J.O.S.B.S. Sharma, Micro Algae: A Potential Source Of Biodiesel., 2 (3) 49 (2012).

15) J. Carvalho, et al. Biodiesel Production by Microalgae and Macroalgae from North Littoral Portuguese Coast. In 1St International Conference WASTES: Solutions, Treatments And Opportunities. 2011. Centro Para A Valorização De Resíduos (CVR).

16) M. Rahman, et al., Biodiesel Production from Microalgae Spirulina Maxima by Two Step Process: Optimization of Process Variable. 10 (2) 140-147 (2017).

17) M. Mashayekhi, et al., Potential for Biodiesel Production and Carbon Capturing From Synechococcus Elongatus: An Isolation and Evaluation Study. 9 230-235 (2017).

18) S.K.M. Yen-Hsun Tseng, D.M. John, F. Leonard. Pease III, Algal Lipid Extraction Using Confined Impinging Jet Mixers. Chemical Engineering Science: X, 2019. Chemical Engineering Science: X 1100002 (2019).

19) Sharma, M., et al., Microalgae as future fuel: real opportunities and challenges. Journal of Thermodynamics \& Catalysis, 2015. 6(1): p. 1.

20) Rajvanshi, S. and M.P. Sharma, Micro algae: a potential source of biodiesel. Journal of Sustainable Bioenergy Systems, 2012. 2(03): p. 49.

21) Silva, C.S.P., et al., Optimization of the cultivation conditions for Synechococcus sp. PCC7942 (cyanobacterium) to be used as feedstock for biodiesel production. Algal Research, 2014. 3: p. 1-7.

22) Sharma, A.K., et al., Exploration of upstream and downstream process for microwave assisted sustainable biodiesel production from microalgae Chlorella vulgaris. 2016. 216: p. 793-800.

23) Wahidin, S., A. Idris, and S.R.M.J.B.t. Shaleh, Ionic liquid as a promising biobased green solvent in combination with microwave irradiation for direct biodiesel production. 2016. 206: p. 150-154.

24) Mashayekhi, M., et al., Potential for biodiesel production and carbon capturing from Synechococcus Elongatus: An isolation and evaluation study. 2017. 9: p. 230-235.

25) Mohan, S.V., et al., Algae oils as fuels, in Biofuels from algae. 2014, Elsevier. p. 155-187.

26) Ball, J., et al., Preliminary Feasibility Study of a Bubble Column CO2 Capture Unit Utilizing Microalgae. 2016.

27) Wang, Q., H. Peng, and B.T. Higgins, Cultivation of green microalgae in bubble column photobioreactors and an assay for neutral lipids. JoVE (Journal of Visualized Experiments), 2019(143): p. e59106.

28) Santoso, A.D. and J.P.J.J.T.L. Susanto, Pengaruh Externalitas Pada Net Energy Ratio Produksi 
Biodiesel Mikroalga= Externalities Effect on Net Energy Ratio of Microalgae Biodiesel Production. 14 (2) 89-94 (2016).

29) S.M. Jones, and S.T.J.A.R. Harrison, Aeration Energy Requirements for Lipid Production by Scenedesmus Sp. in Airlift Bioreactors. 5 249-257 (2014).

30) Lardon, L., Et Al., Life-Cycle Assessment Of Biodiesel Production From Microalgae. 2009, ACS Publications.

31) Ardiansyah, S.R., et al., Tubular Photobioreactor: A Preliminary Experiment Using Synechococcus sp.(Cyanobacteria) Cultivated in NPK Media for Biomass Production as Biofuel Feedstock. Evergreen, 2019. 6(2): p. 157-161.

32) C. Ugwu, H. Aoyagi, and H.J.B.T. Uchiyama, Photobioreactors for Mass Cultivation of Algae. 99 (10) 4021-4028 (2008).

33) N.B. Prihantini, et al. Fatty Acid Characterization of Indigenous Cyanobacterial Strains Isolated from Five Hot Springs in Indonesia. In E3S Web Of Conferences. 2018. EDP Sciences. 